\title{
Penentuan Zonasi Gempa Berdasarkan Pola Penyebaran Gempa Bumi Di Daerah Provinsi Jawa Barat
}

\author{
Siti Azizah Sutisna ${ }^{1^{*}}$, Mimin Iryanti ${ }^{1}$, Judhistira Aria Utama ${ }^{1}$ \\ ${ }^{1}$ Departemen Pendidikan Fisika, Universitas Pendidikan Indonesia \\ Jl. Dr. Setiabudhi No. 299 Bandung 40154 \\ ${ }^{2}$ BMKG KLAS 1 BANDUNG, Jl. Cemara VIII No.66, Kb. Pisang, Sumur Bandung, \\ Jawa Barat 40122 \\ *Penulis Penanggungjawab.E-mail: sitiazizahsutisna@gmail.com
}

\begin{abstract}
ABSTRAK
Provinsi Jawa Barat dibatasi oleh 550' sampai $7^{\circ} 50^{\prime}$ Lintang Selatan dan $104^{\circ} 48^{\prime}$ sampai $108^{\circ} 48^{\prime}$ Bujur Timur. Penelitian ini bertujuan untuk mengetahui seismisitas dan zonasi di daerah Provinsi Jawa Barat. Seismisitas dapat di ketahui dari peta seismisitas berdasarkan kedalaman dan magnitudo, untuk memperoleh peta seismisitas di daerah Provinsi Jawa Barat yaitu dengan menggunakan data gempa bumi tektonik harian atau realtime dengan periode terjadinya gempa bumi pada tahun 2000-2015, yang bersumber dari BMKG (Badan Meteorologi Klimatologi dan Geofisika) Klas 1 Bandung. Data gempa terdiri dari tanggal, waktu terjadinya gempa, lintang, bujur, kedalaman dan magnitudo ( $M \geq 4.5 \mathrm{SR}$ ), data yang ada di proses dengan menggunakan Software Arcgis 10.3 sehingga menjadi peta seismisitas yang telah di klasifikasikan berdasarkan kedalaman dan magnitudo gempa bumi. Zonasi di daerah Provinsi Jawa Barat di peroleh dengan menentukan nilai Percepatan Tanah Maksimum (Peak Ground Acceleration) yang terbagi kedalam 18 kabupaten, dan menentukan nilai PGA dan intensitas gempa di setiap Kabupaten, adapun cara untuk memperoleh nilai PGA dan intensitas gempa yaitu dengan melakukan proses perhitungan data gempa yang ada, dengan menggunakan metode Gutenberg Richter. Sehingga di peroleh kesimpulan berdasarkan peta seismisitas di dapatkan distrubusi gempa bumi berjumlah 792 gempa bumi, serta zonasi gempa bumi di daerah Provinsi Jawa Barat berdasarkan nilai PGA sebesar 25 -29 gal, dan nilai intensitas gempa bumi sebesar V.
\end{abstract}

Kata Kunci : Zonasi gempa; Seismisitas; Software Arcgis 10.3.; Metode Gutenberg Richter; intensitas gempa bumi 


\begin{abstract}
West Java province bounded by $5^{\circ} 50$ 'and $7^{\circ} 50^{\prime}$ south latitude and $104^{\circ} 48$ 'to $108^{\circ} 48^{\prime}$ east longitude. This study aims to determine the seismicity and zoning in the area of West Java Province. Seismicity can be in the know of seismicity map based on the depth and magnitude, to obtain the map of seismicity in the area of West Java province is by using daily tectonic earthquake data or realtime with the period of the earthquake in the year 2000-2015, which is sourced from BMKG (Meteorology and Geophysics) Class 1 Bandung. Seismic data consists of the date, the time of the earthquake, latitude, longitude, depth and magnitude ( $M \geq 4.5 \mathrm{SR}$ ), the data that is in the process of using ArcGIS 10.3 software so that a map of seismicity which has been classified based on the depth and magnitude of the earthquake. Zoning in the area of West Java province was obtained by determining the value of the Acceleration of Land Maximum (Peak Ground Acceleration), divided into 18 districts, and determine the value of PGA and intensity of earthquakes in each district, as for how to obtain the value of PGA and earthquake intensity by performing the calculation process existing seismic data, using Gutenberg Richter. Thus obtained conclusions based on maps of seismicity in distrubusi get earthquakes amounted to 792 earthquakes, and earthquake zoning in the area of West Java Province based on the value of the PGA of 25-29 gal and earthquake intensity value of $\mathrm{V}$.
\end{abstract}

Keywords: Zoning earthquake; seismicity; Software ArcGIS 10.3.; Methods Gutenberg Richter earthquake intensity.

\title{
1. Pendahuluan
}

Jawa Barat merupakan salah satu Provinsi di Pulau Jawa yang terdiri dari 18 kabupaten. Dengan kawasan pantai utara merupakan dataran rendah, dan di bagian tengah merupakan pegunungan dengan titik tertinggi adalah Gunung Ciremay, yang berada di sebelah barat daya Kota Cirebon. Dengan sungai yang berpotensi yaitu Sungai Citarum dan
Sungai Cimanuk. Wilayah Laut Pesisir Jawa Barat memiliki potensi gempa bumi tsunami, yang di sebabkan oleh adanya patahan aktif yang dapat menimbulkan terjadi bencana alam seperti gempa bumi [1].

Pada wilayah Jawa Barat terdapat sejumlah patahan aktif sehingga relatif rawan terhadap gempa bumi yang disebabkan oleh pertemuan lempeng. 
Patahan aktif yang terdapat di Jawa Barat diantaranya adalah patahan Cimandiri yaitu patahan yang membentang dari Pelabuhan Ratu Sukabumi sampai ke Cianjur, adapun patahan yang lain yaitu patahan Baribis yang berada di Wilayah Majalengka dan Kuningan, dan patahan Lembang yang berada di wilayah Lembang Bandung [2].

Adapun yang menjadi referensi sebagai penelitian ini yaitu penelitian yang telah dahulu di lakukan oleh Mohammad Hairid Zulhi pada skripsi yang di tulis tahun 2006 yang berjudul "Penentuan Zonasi Gempa Berdasarkan Pola Penyebaran Gempa Bumi dengan Menggunakan Software Arc View 3.3 ESRI di Daerah Provinsi Gorontalo", yang membedakan penelitian ini dengan yang terdahulu yaitu adanya penentuan zonasi yang di peroleh dari hasil pengolahan data gempa bumi, dengan menggunakan perhitungan yang berdasarkan metode pada Gutenberg Richter, dengan perhitungan tersebut maka akan di peroleh nilai PGA ( Peak Ground Acceleration) atau Percepatan Tanah Maksimum di masing - masing Kabupaten, nilai PGA ini digunakan sebagai nilai acuan untuk menentukan zonasi gempa bumi di Provinsi Jawa barat.

Dengan melakukan penentuan zonasi gempa berdasarkan pola penyebaran gempa bumi untuk menentukan seismisitas di Provinsi Jawa Barat yaitu dengan menggunakan Software Arcgis 10.3 yang di proses sehingga menjadi peta seismisitas sebagai pola penyebaran gempa, sehingga dari hasil penelitian tersebut dapat dijadikan informasi untuk masyarakat sebagai salah satu mitigasi bencana.

Gempa bumi adalah gejala alami yang berupa gerakan, goncangan, atau getaran tanah yang ditimbulkan oleh adanya sumber - sumber getaran tanah akibat terjadi patahan atau sesar yang di sebabkan oleh aktivitas tektonik, dan aktivitas vulkanik, dan juga dapat berupa hantaman dari benda langit seperti meteor yang jatuh ke bumi [3].

Hiposentrum adalah pusat gempa yang ada di dalam bumi. Hiposentrum diukur melalui gelombang seismik. Penentuan hiposenter diantaranya adalah :

a. Metoda Lokus (D)

$$
\begin{aligned}
& \text { Karena } \mathrm{V}_{\mathrm{p}}<\mathrm{V}_{\mathrm{s}}, \text { maka } \\
& D_{1}=\mathrm{V}_{\mathrm{p}} \cdot \mathrm{t}_{\mathrm{p}}-\mathrm{t}_{p} \\
& \text { dan } \quad D_{2}=\mathrm{V}_{\mathrm{s}} \cdot \mathrm{t}_{\mathrm{s}}
\end{aligned}
$$

Karena $\mathrm{t}_{s}-\mathrm{t}_{p}, \frac{\frac{D_{2}}{V s}-\frac{D_{1}}{V p}}{V^{2}}$

$$
\begin{aligned}
& D_{1}=D_{2}=D \\
& \mathrm{t}_{s}-\mathrm{t}_{p}=D\left(\frac{1}{V s}-\frac{1}{V p}\right)
\end{aligned}
$$

Maka: $t_{s}-t_{p}=\frac{D\left(v_{p}-v_{s}\right)}{v_{p} v_{s}}$

$D=\frac{v_{p} v_{s}}{V_{p}-v_{s}}\left(t_{s}-t_{p}\right)=K\left(t_{s}-t_{p}\right)$ 
dengan :

Vp adalah Kecepatan jalar gelombang $\mathrm{P}$

Vs adalah Kecepatan jalar gelombang $S$

Tp adalah Waktu tiba gelombang $\mathrm{P}$ di stasiun

Ts adalah Waktu tiba gelombang $\mathrm{S}$ di stasiun

$\mathrm{K}$ adalah Konstanta Omori.

b. Persamaan Pythagoras

$\mathrm{H}=\sqrt{E^{2}+h^{2}}$

dengan :

$\mathrm{H}$ adalah Hiposenter gempa

E adalah Episenter gempa

$\mathrm{H}$ adalah kedalaman gempa

Episentrum adalah gelombang hasil dari rambatan dari hiposentrum. Saat hiposentrum menghasilkan satu titik gempa, gempa itu memiliki gelombang yang membentuk melingkar [4]. Penentuan Episenter diantaranya adalah sebagai berikut :

Untuk menentukan episenter gempa menggunakan perhitungan yang menggunakan persamaan yang berdasarkan metode Gutenberg Richter maka diberikan persamaan seperti dibawah ini. [5]

Episenter

$111 \times($

$\left.\left.\sqrt{\left((\text { long } 1-\text { long } 2)^{\wedge} 2+\left(\text { lat } 1-{\text { lat } 2)^{\wedge} 2}^{2}\right.\right.}\right)\right)$ dengan :

long1 adalah Longitude lokasi gempa bumi yang telah terjadi sesuai data . long2 adalah Longitude lokasi gempa bumi di suatu daerah (titik koordinat Kabupaten). lat1 adalah Latitude lokasi gempa bumi yang telah terjadi sesuai data . lat2 adalah Latitude lokasi gempa bumi di suatu daerah (titik koordinat Kabupaten).

Magnitudo merupakan kekuatan gempa bumi. Suatu harga Magnitudo diperoleh sebagai hasil analisis tipe gelombang seismik tertentu (berupa rekaman getaran tanah yang tercatat paling besar) dengan memperhitungkan koreksi jarak stasiun pencatat ke episenter. [6]

Untuk menentukan magnitudo gempa bumi menggunakan persamaan :

$\mathrm{M}=2,85 \log \mathrm{D}-2,53+0,0014 \Delta$

dengan :

$\mathrm{D}$ adalah jarak dalam kilometer

$\Delta$ adalah lamanya gempa tercatat

Peak Ground Acceleration adalah ukuran bagaimana permukaan bumi bergetar (accelerated) di suatu daerah tertentu. Satuan Peak Ground Acceleration (PGA) dinyatakan dalam $\mathrm{g}$ (percepatan gravitasi bumi) atau dalam Gal. $1 \mathrm{~g}=9,81 \mathrm{~m} / \mathrm{s} 2$ sedangkan $1 \mathrm{Gal}=$ $0,01 \mathrm{~m} / \mathrm{s}^{2}$ sehingga $1 \mathrm{~g}=981 \mathrm{Gal}$. Nilai PGA dapat dihitung dengan mempergunakan fungsi atenuasi, yaitu suatu fungsi yang menggambarkan korelasi antara intensitas gerakan tanah 
setempat, magnitudo gempa, serta jarak dari suatu titik dalam daerah sumber gempa.

Pada penelitian ini Metode yang di gunakan untuk menentukan nilai PGA yaitu menggunakan Metode Gutenberg Richter. Untuk menentukan nilai PGA yaitu terlebih dahulu menentukan nilai Intensitas Maksimum gempa bumi dengan menggunakan persamaan sebagai berikut:

$$
I_{m}=1,5 \times(\mathrm{M}-0,5)
$$

dengan :

Im adalah Intensitas maksimum gempa bumi

$\mathrm{M}$ adalah magnitudo gempa bumi (SR)

Setelah menentukan nilai Intensitas maksimum gempa bumi, dapat diperoleh nilai Intensitas gempa bumi dengan menggunakan persamaan sebagai berikut:

$$
I_{x}=I_{m} \times(2,7813)^{(-0,007869 x d)}
$$

dengan :

Ix adalah Intensitas gempa bumi

$\mathrm{D}$ adalah episenter gempa bumi

Setelah diperoleh nilai Intensitas maksimum gempa bumi dan nilai Intensitas gempa dapat digunakan untuk menentukan nilai PGA atau nilai percepatan tanah. Berikut merupakan persamaan untuk menentukan nilai PGA :

$$
\text { PGA }=(10)^{\left(\frac{I x}{8}-0,5\right)}
$$

dengan :

PGA adalah Peak Ground Acceleration (gal)

Ix adalah intensitas gempa.

Intensitas gempa bumi adalah ukuran kerusakan akibat gempabumi berdasarkan hasil pengamatan efek gempabumi terhadap manusia, struktur bangunan dan lingkungan pada tempat tertentu. Besarnya intensitas di suatu tempat tidak tergantung dari besarnya kekuatan gempabumi (Magnitudo) saja namun juga tergantung dari besarnya jarak tempat tersebut ke sumber gempabumi dan kondisi geologi setempat [7].

SIG adalah Skala Intensitas Gempabumi. Skala ini menyatakan dampak yang ditimbulkan akibat terjadinya gempabumi. Skala Intensitas Gempabumi (SIG-BMKG) digagas dan disusun dengan mengakomodir keterangan dampak gempabumi berdasarkan tipikal budaya atau bangunan di Indonesia. Skala ini disusun lebih sederhana dengan hanya memiliki lima tingkatan yaitu I-V. Adapun berikut merupakan tabel dari SIG BMKG yaitu sebagai berikut: 


\begin{tabular}{|c|c|c|c|c|}
\hline $\begin{array}{c}\text { Skala SIG } \\
\text { BMKG }\end{array}$ & $\begin{array}{l}\text { Deskripsi } \\
\text { Sederhana }\end{array}$ & Deskrispsi Rinci & $\begin{array}{l}\text { Skala } \\
\text { MMI }\end{array}$ & $\begin{array}{l}\mathrm{PGA} \\
\text { (gal) }\end{array}$ \\
\hline I & $\begin{array}{l}\text { TIDAK } \\
\text { DIRASAKAN } \\
\text { (Not Felt) }\end{array}$ & $\begin{array}{l}\text { Tidak dirasakan atau dirasakan } \\
\text { hanya oleh beberapa orang tetapi } \\
\text { terekam oleh alat. }\end{array}$ & I-II & $<2.9$ \\
\hline II & $\begin{array}{l}\text { DIRASAKAN } \\
(\text { Felt })\end{array}$ & $\begin{array}{l}\text { Dirasakan oleh orang banyak } \\
\text { tetapi tidak menimbulkan } \\
\text { kerusakan. Benda-benda ringan } \\
\text { yang digantung bergoyang dan } \\
\text { jendela kaca bergetar. }\end{array}$ & III-V & $2.9-88$ \\
\hline III & $\begin{array}{l}\text { KERUSAKAN } \\
\text { RINGAN } \\
\text { (Slight } \\
\text { Damage) }\end{array}$ & $\begin{array}{l}\text { Bagian non struktur bangunan } \\
\text { mengalami kerusakan ringan, } \\
\text { seperti retak rambut pada dinding, } \\
\text { genteng bergeser ke bawah dan } \\
\text { sebagian beriatuhan }\end{array}$ & VI & $89-167$ \\
\hline IV & $\begin{array}{l}\text { KERUSAKAN } \\
\text { SEDANG } \\
\text { (Moderate } \\
\text { Damage) }\end{array}$ & \begin{tabular}{|l} 
Banyak \\
dinding betakan terjadi pada \\
sebagian robunan sederhana, \\
Sebagian plester dinding lecahas. \\
Hampir sebagian besar genteng \\
bergeser ke bawah atau jatuh \\
Struktur bangunan mengalami \\
kerusakan ringan sampai sedang.
\end{tabular} & VII-VIII & 168-564 \\
\hline $\mathrm{v}$ & $\begin{array}{l}\text { KERUSAKAN } \\
\text { BERAT } \\
\text { (Heany } \\
\text { Damage) }\end{array}$ & $\begin{array}{l}\text { Sebagian besar dinding bangunan } \\
\text { permanen roboh. Struktur } \\
\text { bangunan mengalami kerusakan } \\
\text { berat. Rel kereta api melengkung }\end{array}$ & IX-XII & $>564$ \\
\hline
\end{tabular}

Gambar 1. Tabel Skala Intensitas Gempa bumi (SIG) BMKG [8]

Zonasi gempa bumi adalah pembagian atau pemecahan suatu areal menjadi beberapa bagian, dalam hal ini pembagian tersebut merupakan daerah yang di gunakan untuk menentukan gempa bumi.

\section{Metode Penelitian}

Data yang digunakan pada penelitian ini merupakan data sekunder berupa data gempa bumi tektonik di daerah provinsi Jawa Barat periode 2000-2015 yang diperoleh dari Badan Meteorologi Klimatologi dan Geofisika (BMKG) Stasiun Geofisika Klas 1 Bandung.

Gambaran umum mengenai bagaimana setiap data gempa yang di peroleh dari BMKG yaitu menggunakan alat pengukur gempa bumi yang disebut dengan seismograf dengan nama alat Broadband Seismograf. Jangkauan frekuensi yang dimiliki broadband seismograf lebih luas dari pada seismograf biasa. Frekuensi berkisar antara 0,01 hingga 50 Hertz. Broadband seismograf sensitif terhadap perubahan berbagai suhu dan atmosfer. Oleh karena itu seismograf ini memerlukan tempat khusus dalam pemasangannya. Tempat tersebut biasa berupa bunker di bawah lapisan tanah dengan ukuran seluas satu meter persegi. Di sekitar seismograf juga ditaburkan pecahanpecahan gabus untuk menutupi badan seismograf. Cara kerja dari seismograf digital ini yaitu mendeteksi dan merekam getaran kemudian mengirim data getaran menuju amplifier. Dari amplifier diteruskan menuju alat yang disebut analog to digital converter (ADC) lalu dikirim ke komputer. Software di dalam komputer selanjutnya mengolah data yang dihasilkan oleh broaddband seiemograf. Software yang diinstall pada komputer biasanya bernama NetRec atau MnoST.

\section{Hasil Dan Pembahasan}

Peta Seismisitas Daerah Provinsi Jawa Barat berdasarkan Magnitudo

\section{Gempa}

Dari data sekunder yang berupa data harian gempa bumi tektonik tahun 2000-2015 yang terdiri dari tanggal, waktu terjadinya gempa, lintang , bujur, magnitudo, dan kedalaman. Besarnya magnitudo gempa yang digunakan yaitu $\geq 4$ SR. Kemudian data yang telah ada ekstrapolasi ke dalam bentuk basis data [9]. Kemudian basis data tersebut diplot dengan 
menggunakan Sofware Argis 10.3, sehingga diperoleh peta seismisitas berdasarkan magnitudo yang dapat dilihat pada (gambar 2) berikut.

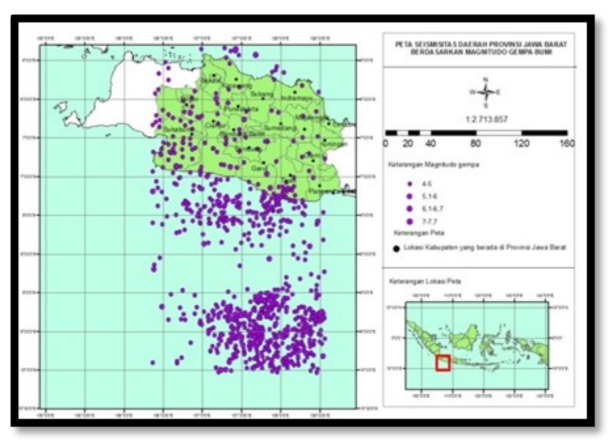

Gambar 2. Peta seismisitas berdasarkan magnitudo gempa bumi.

Adapun penyebaran gempa bumi berdasarkan magnitudo di daerah Provinsi Jawa Barat yang terdiri dari 18 Kabupaten, yaitu diperoleh hasil sebagai berikut.

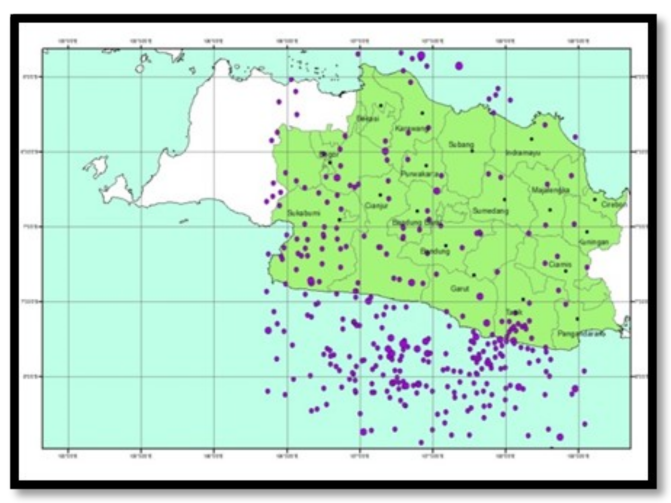

Gambar 3. Persebaran Peta seismisitas berdasarkan magnitudo gempa bumi.

Peta seismisitas berdasarkan magnitudo di bagi kedalam 3 bagian, berdasarkan rentang magnitudo, yaitu dengan besar magnitudo 4,5-5 SR, dengan besar magnitudo 5-6 SR, dan dengan besar magnitudo lebih besar dari $6 \mathrm{SR}$.

\section{Peta Seismisitas Daerah Provinsi Jawa}

\section{Barat berdasarkan Kedalaman Gempa}

Seperti peta seismisitas berdasarkan magnitudo gempa, peta seismisitas berdasarkan kedalaman juga memiliki tahapan yang sama yang membedakannya adalah pada saat memproses ke dalam Software Tools yang digunakan untuk magnitudo gempa di ganti dengan kedalaman gempa. sehingga diperoleh peta seismisitas berdasarkan kedalaman yang dapat dilihat pada (gambar 4) berikut.

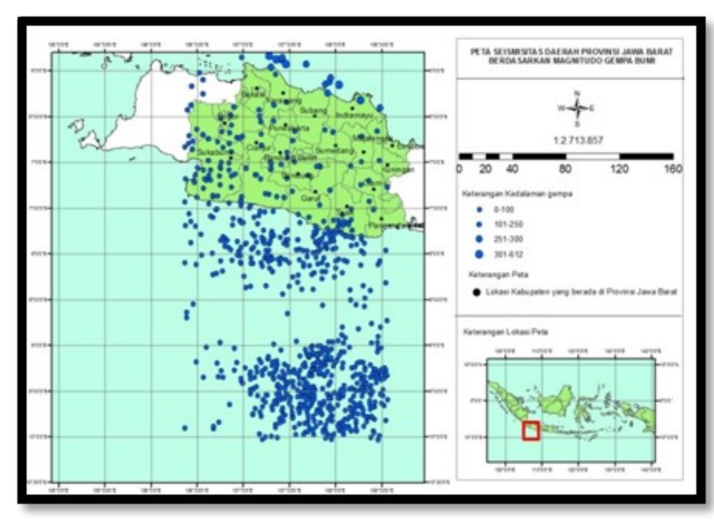

Gambar 4. Peta seismisitas berdasarkan kedalaman gempa bumi.

Adapun penyebaran gempa bumi berdasarkan kedalaman di daerah Provinsi Jawa Barat yang terdiri dari 18 Kabupaten, yaitu diperoleh hasil sebagai berikut. 


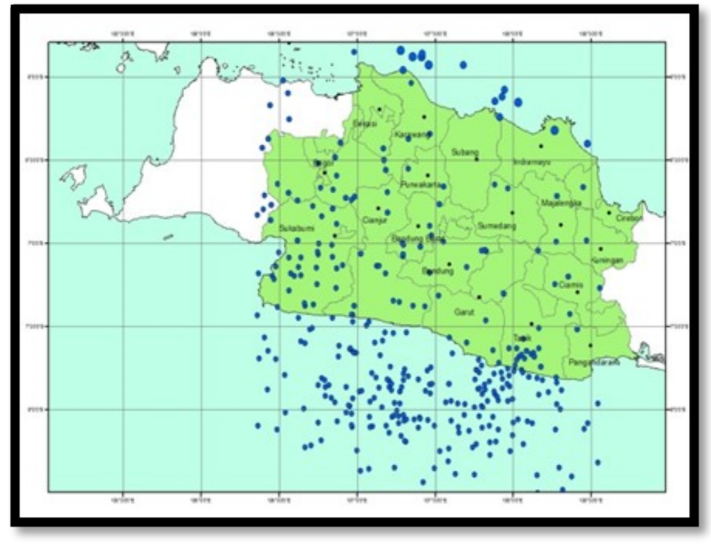

Gambar 5. Penyebaran peta seismisitas berdasarkan kedalaman gempa bumi.

Peta seismisitas berdasarkan kedalaman di bagi kedalam 3 bagian, berdasarkan rentang magnitudo, yaitu dengan besar kedalaman 0-60 KM, dengan besar kedalaman 60-300 KM, dan dengan besar kedalaman lebih besar dari $300 \mathrm{KM}$.

\section{Zonasi Gempa bumi di Daerah Provinsi Jawa Barat}

Dari data sekunder yang berupa data harian gempa bumi tektonik tahun 20002015 yang terdiri dari tanggal, waktu terjadinya gempa, lintang, bujur, magnitudo, dan kedalaman, yang berlokasi di daerah Provinsi Jawa Barat. Maka untuk menentukan zonasi gempa bumi dapat dilakukan dengan cara menghitung data yang ada dengan menggunakan metode Gutenberg Richter. Maetode ini digunakan untuk menentukan suatu kejadian gempa yang berdasarkan kerusakan yang telah disebabkan oleh gempa sehingga diperoleh nilai Intensitas gempa bumi.
Provinsi Jawa Barat terdiri dari 18 Kabupaten dan 9 kota di dalamnya. Dengan pembagian wilayah berdasarkan kabupaten maka dapat diperoleh penentuan zonasi gempa bumi di daerah Provinsi Jawa Barat. Dari data yang ada, telah dilakukan perhitungan untuk menentukan Intensitas gempa bumi di setiap Kabupaten di Provinsi Jawa Barat dan percepatan tanah. Proses perhitungan data gempa bumi dapat dilihat dilampiran. Hasil perhitungan percepatan tanah setiap Kabupaten di daerah Provinsi Jawa Barat, diperoleh sebagai berikut.

\begin{tabular}{|l|l|l|l|l|l|}
\hline \multicolumn{1}{|c|}{ Kabupaten } & $\begin{array}{c}\text { Latitud } \\
(\mathrm{rad})\end{array}$ & $\begin{array}{c}\text { Longitud } \\
(\mathrm{rad})\end{array}$ & $\begin{array}{c}\text { Intensitas } \\
\text { Maksimum }\end{array}$ & $\begin{array}{c}\text { Intensitas } \\
\text { gempa }\end{array}$ & $\begin{array}{c}\text { Nilai PGA } \\
\text { Rata-rata }\end{array}$ \\
\hline Ciamis & 0,146 & 1,893 & 5,545 & 5,423 & 28,141 \\
\hline Garut & 0,128 & 1,880 & 5,545 & 5,407 & 27,759 \\
\hline Pangandaran & 0,134 & 1,895 & 5,545 & 5,395 & 27,442 \\
\hline Bandung & 0,122 & 1,879 & 5,545 & 5,386 & 27,281 \\
\hline Bandung barat & 0,120 & 1,874 & 5,545 & 5,739 & 27,144 \\
\hline Tasik & 0,120 & 1,874 & 5,545 & 5,379 & 27,144 \\
\hline Sumedang & 0,120 & 1,883 & 5,545 & 5,374 & 26,996 \\
\hline Cianjur & 0,120 & 1,862 & 5,545 & 5,336 & 26,822 \\
\hline Sukabumi & 0,119 & 1,862 & 5,545 & 5,363 & 26,754 \\
\hline Majalengka & 0,119 & 1,888 & 5,545 & 5,363 & 26,732 \\
\hline Kuningan & 0,122 & 1,894 & 5,545 & 5,362 & 26,658 \\
\hline Purwakarta & 0,115 & 1,879 & 5,545 & 5,357 & 26,656 \\
\hline Subang & 0,112 & 1,879 & 5,545 & 5,346 & 26,399 \\
\hline Cirebon & 0,117 & 1,894 & 5,545 & 5,345 & 26,282 \\
\hline Indramayu & 0,113 & 1,888 & 5,545 & 5,340 & 26,216 \\
\hline Bogor & 0,112 & 1,863 & 5,545 & 5,338 & 26,207 \\
\hline Karawang & 0,109 & 1,873 & 5,545 & 5,334 & 26,160 \\
\hline Bekasi & 0,108 & 1,869 & 5,545 & 5,325 & 25,972 \\
\hline
\end{tabular}

Dari perolehan hasil pengolahan data tersebut. Maka nilai yang digunakan untuk menentukan zonasi di daerah Provinsi Jawa Barat yaitu dengan menggunakan nilai percepatan tanah maksimum (PGA) rata - rata. Dengan nilai percepatan tanah tersebut yang diperoleh dari data gempa bumi, dapat dilihat bahwa nilai percepatan tanah yang paling besar di Provinsi Jawa Barat 
yaitu berlokasi di daerah Kabupaten Ciamis, dengan nilai pecepatan tanah untuk kabupaten Ciamis sebesar 28,141 gal.

Intenseitas gempa yang di peroleh untuk Kabupaten yang terdapat di daerah Provinsi Jawa Barat yaitu pada intensitas gempa $\mathrm{V}$, sedangkan menurut MMI Intensitas Gempa Bumi yang di tetapkan oleh BMKG bahwa dari hasil yang telah di peroleh Skala Intensitas Gempa Bumi berada di skala II , deskripsi sederhana yaitu dirasakan (felt), deskripsi rinci yaitu gempa bumi dirasakan oleh orang banyak tetapi tidak menimbulkan kerusakan, dan bendabenda ringan yang digantung bergoyang dan jendela kaca bergetar, skala MMI berada di kisaran III-V, dengan nilai Percepatan Tanah Maksimum (PGA) 2.9-88 gal.

Dengan nilai percepatan tanah yang telah diperoleh hasil perhitungan setiap Kabupaten di Provinsi Jawa Barat, nilai di setiap Kabupaten berbeda, dengan nilai terkecil yaitu berlokasi di kabupaten Bekasi dengan nilai percepatan tanah yaitu 25,972 gal. Sedangkan intensitas gempa yang terjadi di setiap Kabupaten di daerah Provinsi Jawa Barat memiliki nilai sama yaitu $\mathrm{V}$.

\section{Analisis zonasi gempa bumi di daerah Provinsi Jawa Barat}

Berdasarkan hasil dari perhitungan percepatan tanah maksimum (PGA) dengan menggunakan data gempa dan menggunakan metode perhitungan Gutenberg Richter. Maka nilai yang diperoleh di setiap kabupaten yang berada di Jawa barat memiliki nilai yang berbeda. Dengan nilai percepatan yang paling tinggi dengan nilai intensitas gempa yang besar yaitu berlokasi di Kabupaten Ciamis. Dari perolehan hasil percepatan tanah yang di gabungkan kedalam pola penyebaran gempa yaitu peta seismisitas di daerah Provinsi Jawa Barat maka akan diperoleh hasil sebagai berikut.

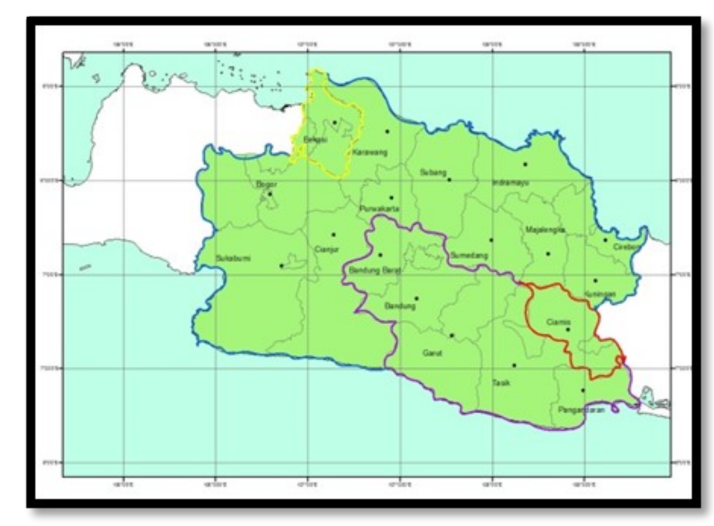

Gambar 6. Peta zonasi dari percepatan tanah maksimum di daerah Provinsi Jawa Barat

Adapun tabel pembagian zonasi berdasarkan nilai percepatan tanah di daerah Provinsi Jawa Barat yang terbagi kedalam 18 Kabupaten diantaranya sebagai berikut. 


\begin{tabular}{|l|c|c|c|}
\hline \multicolumn{1}{|c|}{ Kabupaten } & Nilai PGA Rata-rata & Intensitas gempa & Keterangan \\
\hline Ciamis & 28,141 & $\mathrm{~V}$ & Aktivitas 1 \\
\hline Garut & 27,759 & $\mathrm{~V}$ & Aktivitas 2 \\
\hline Pangandaran & 27,442 & $\mathrm{~V}$ & Aktivitas 2 \\
\hline Bandung barat & 27,281 & $\mathrm{~V}$ & Aktivitas 2 \\
\hline Bandung & 27,144 & $\mathrm{~V}$ & Aktivitas 2 \\
\hline Tasik & 27,144 & $\mathrm{~V}$ & Aktivitas 2 \\
\hline Sumedang & 26,996 & $\mathrm{~V}$ & Aktivitas 3 \\
\hline Cianjur & 26,822 & $\mathrm{~V}$ & Aktivitas 3 \\
\hline Sukabumi & 26,754 & $\mathrm{~V}$ & Aktivitas 3 \\
\hline Majalengka & 26,732 & $\mathrm{~V}$ & Aktivitas 3 \\
\hline Kuningan & 26,658 & $\mathrm{~V}$ & Aktivitas 3 \\
\hline Purwakarta & 26,656 & $\mathrm{~V}$ & Aktivitas 3 \\
\hline Subang & 26,399 & $\mathrm{~V}$ & Aktivitas 3 \\
\hline Cirebon & 26,282 & $\mathrm{~V}$ & Aktivitas 3 \\
\hline Indramayu & 26,216 & $\mathrm{~V}$ & Aktivitas 3 \\
\hline Bogor & 26,207 & $\mathrm{~V}$ & Aktivitas 3 \\
\hline Karawang & 26,160 & $\mathrm{~V}$ & Aktivitas 3 \\
\hline Bekasi & 25,972 & V & Aktivitas 4 \\
\hline
\end{tabular}

Tabel di atas merupakan tabel pembagian zonasi berdasarkan nilai percepatan tanah di daerah Provinsi Jawa Barat yang terbagi kedalam 18 Kabupaten. Dari 18 kabupaten yang ada pembagian zonasi gempa bumi terbagi ke dalam empat bagian, diantaranya adalah dengan keterangan Aktifitas 1 hingga 4.

Untuk aktivitas 1 yaitu dengan nilai PGA $\geq 28,0$ gal, dengan wilayah yang meliputi Kabupaten Ciamis.

Untuk aktivitas 2 yaitu dengan nilai PGA $\geq 27,0$ gal, dengan wilayah yang meliputi Kabupaten Garut, Kabupaten Pangandaran, Kabupaten Bandung Barat, dan Kabupaten Bandung dan Kabupaten Tasik.

Untuk aktivitas 3 yaitu dengan nilai PGA $\geq 26,0$ gal, dengan wilayah yang meliputi Kabupaten sumedang, Kabupaten Cianjur, Kabupaten Sukabumi, Kabupaten Majalengka, Kabupaten Kuningan, Kabupaten Purwakarta, Kabupaten Subang, Kabupaten Cirebon, Kabupaten Indramayu, Kabupaten Bogor, dan Kabupaten Karawang.
Untuk Aktivitas 4 yaitu dengan nilai PGA $\geq 25,0$ gal, dengan wilayah yang meliputi Kabupaten Bekasi.

\section{Kesimpulan}

Berdasarkan peta seismisitas daerah Provinsi Jawa Barat periode 20002015, ditinjau dari kedalaman gempa bumi pada 0-60 km terjadi gempa bumi sebanyak 634 gempa bumi, pada 60-300 km terjadi gempa bumi sebanyak 128 gempa bumi, dan pada kedalaman lebih dari $300 \mathrm{~km}$ terjadi sebanyak 10 gempa bumi. Serta di tinjau berdasarkan magnitudo gempa bumi pada 4,5-5 SR terjadi 374 gempa bumi, pada 5-6 SR terjadi 98 gempa bumi, pada 6-7 SR terjadi gempa sebanyak 9 gempa bumi.

Zonasi gempa bumi di daerah Provinsi Jawa Barat dari nilai PGA dan intensitas gempa bumi, diperoleh nilai PGA sebesar 25-29 gal, dan nilai intensitas gempa bumi V. Dari hasil pengolahan data gempa bumi untuk setiap kabupaten yang berada di Provinsi Jawa Barat yang berjumlah 18 Kabupaten. Nilai PGA yang paling tinggi adalah Kabupaten Ciamis dan nilai PGA yang paling kecil adalah Kabupaten Bekasi.

\section{Daftar Pustaka}

1. Pemerintah Provinsi Jawa Barat. (2017). Kondisi Geografis Jawa 
Barat. (jabarprov.go.id) diakses pada tanggal 14 Februari 2017.

2. Pannekoek. (1949). Garis Besar Geomorfologi Pulau Jawa.

Diterjemahkan Budi Busri. Jakarta: Tanpa Penenerbit.

3. Tjasyono, Bayong HK. (2003). Geosains. Bandung: Institut Teknologi Bandung.

4. Waluyo, et. Al. Penentuan Episenter Gempa - Gempa Mikro atau Lokal dengan Menggunakan Tiga Buah Seismograf. Bandung: Makalah PIT HAGI VII.

5. Pranata, D., Erlansari, A., \& Setiawan, Y. (2017). SISTEM INFORMASI GEOGRAFIS PEMETAAN PERCEPATAN GETARAN TANAH DAN TINGKAT RESIKO KERUSAKAN GEMPA BUMI DENGAN MENGGUNAKAN METODE GUTENBERG RICHTER DAN INTENSITAS SKALA MERCALLI (Studi Kasus: Provinsi Bengkulu). Rekursif: Jurnal Informatika, 5(1).

6. Lay, T dan Wallance, T, C. (1995). Modern global seismology. (https:// books.google.com.au) diakses tanggal 13 Februari 2017.

7. Louie, J. (1996). The Modified Mercalli Scale of Earthquake intensity. (crack.seismo.unr.edu) diakses tanggal 14 Februari 2017.

8. Badan Meteorologi, Klimatologi, dan Geofisika. (2017). Skala Intensitas Gempa bumi (http:// www.bmkg.go.id), diakses tanggal 15 Februari 2017.

9. Sarwono, J (2006). Teori Analisis Korelasi, Mengenal Analisis Korelasi. (http:// www.jonathansarwono.info/korelasi/ korelasi.htm), di akses tanggal 05 Oktober 2017. 